\title{
Negotiating Nation-building and Citizenship through the Truth and Reconciliation Committee's 'Dramatic' Spheres: A Reading of Two Post-apartheid Plays
}

\author{
Busuyi Mekusi*
}

\begin{abstract}
Having a voice, either at the level of the individual or the community, has been one of the atavistic ways of defining or asserting humanity. This allows for the inscription of the twin-capped hegemony of successes or victories and frustrations at both the private locus and the public sphere. The disruptions of this possibility by rifts between natives in pre-colonial South Africa were aggravated in the heat of the colonial suppression it suffered, and was compounded by the operation of apartheid rule. By reason of this misrule, voices were suppressed, with a few cacophonies of dissention breaking forth. The culmination of these disenchantments into the demise of apartheid significantly presaged the need for reconstruction and redefinition of citizenship and cohabitation, and hence the necessity for establishing a public sphere, or put alternatively, a public domain in the form of the Archbishop Desmond Tutu's Truth and Reconciliation Commission. This paper, therefore, seeks to interrogate the dramatic world(s) created using the material properties of the TRC in John Kani's Nothing but the Truth and Zakes Mda's The Bells of Amersfoort. The paper argues that the domination and manipulation of this public realm by the state at the expense of the individual is not only counterproductive, but constitutes a denial of the relevance of such spheres. The paper, going by indices in the plays, therefore, concludes that every individual should not only be: given a voice, and be heard, but be allowed equal unbiased participation. Otherwise, the public sphere would not just be impotent, but the idea of nation-building and desirable citizenship would be a mere ruse.
\end{abstract}

* Department of African Literature, University of the Witwatersrand, Johannesburg, South Africa. Email: mekusotayo@yahoo.com 


\section{Résumé}

Avoir une voix, que ce soit au niveau individuel ou communautaire, a été l'un des moyens ataviques de définition et d'affirmation de l'humanité. Cela tient compte de l'inscription de l'hégémonie à double face des succès ou victoires et des frustrations tant au niveau de l'espace privé que de la sphère publique. Les perturbations de cette possibilité par des clivages entre les autochtones en Afrique du Sud précoloniale ont empiré sous le feu de la répression coloniale que ce pays a subie et ont été aggravées par le régime d'apartheid. En raison de cette mauvaise administration, des voix ont été réprimées, avec quelques cacophonies de dissension. Le paroxysme de ces désenchantements vers la fin de l'apartheid présageait significativement la nécessité de la reconstruction et la redéfinition de la citoyenneté et de la cohabitation, et donc la nécessité d'établir une sphère publique, ou sinon établir un domaine public, sous la forme de la Commission vérité et réconciliation de l'archevêque Desmond Tutu. Cet article vise donc à examiner le (s) monde (s) dramatique (s) créé (s) à l'aide des propriétés matérielles du TRC dans Nothing but the Truth de John Kani et The Bells of Amersfoort de Zakes Mda. L'article soutient que la domination et la manipulation de ce domaine public par l'État au détriment de l'individu n'est pas seulement nuisible, mais constitue un rejet de la pertinence de telles sphères. Cet article, en parcourant les indexes de ces pièces, conclut donc que tout individu doit non seulement avoir une voix et être entendu, mais aussi jouir de son droit à une participation égale impartiale. Sinon, la sphère publique ne serait impuissante et l'idée de construction de la nation et de la citoyenneté souhaitable ne serait rien d'autre qu'un simple stratagème.

\section{Introduction}

As variegated as elements in nature are, human beings seem to suggest that they have achieved a mastery of virtually all these elements as they deploy them for constructing social, economic and political advantages. This unique deployment does not merely give humans the control over natural things, but also allows one individual to assume a more advantageous platform than the others. It is, therefore, not unusual for people to be locked into a cold war of superiority or domination as it is characteristic of human beings, not only to attain sovereignty but acquire power through which some or others are consigned into the position of servitude. This goes to say, therefore, that space is one of the available devices that allow for the externalisation of the domineering nature of mankind through the acquisition of both power and the lever to control those under his or her domination. The conjectures of space are as varying as the assumptions they make and the meanings they create. It then follows that the manifestations of space would be dependent 
on the particular signification that is targeted at one point or the other. However, fundamental is the fact that space, in its ontology, talks about the vacuum, the blank spot, centre, platform or fulcrum offered to an agent to function either minimally or maximally. The functionality of the agent is at the same time consequent on the nature and character of its existence. This implies that the performance of a concept, subject or object, derives from the symbiotic relationship between the physicality of the given space and the ontological configuration of the relational element. This receives confirmation from the view of Doreen Massey (2005:20), making reference to what is called 'a long and illustrious history', that 'there is an association between the spatial and the fixation of meaning'. In another vein, Massey (ibid) holds that 'representation - indeed conceptualization - has been conceived of as spatialisation'. The mention made of space at this point is important to the extent of its interrelatedness to 'sphere' or 'domain'. Given the foregoing, it should be made clear that space could be characterised by both size and nature. By size we mean whether space is overt, small, cylindrical, opaque, sinuous, shallow, expansive, and so on, while by nature it implies that space could be simply evaluated on whether it is public or private. However, suffice to make it clear that the possibilities adducible to space, as far as its characteristics are concerned, are not limited to the above. It is significant, however, that the emphasis in this paper shall be given to space in the reality of its nature to interrogate whether it is public or private, or both, or neither.

\section{Spatialisation and Meaning-making}

So much theorising has been done on space $^{1}$ as a concept. As much as a regurgitation of that would not be necessary in this circumstance, a reading of some of the manifestations shall be done so as to establish a platform for our take-off. Space is conceived as 'an open, heterogeneous, and indeterminate field' which, like the subject, is a void to 'be filled, contested and reconfigured through contingent and partially determined social relations, practices and meanings' (Natter and Jones III 1997:149-150). In another vein, Benno Werlen (1993:1) examines these conjectures by looking at the activities of geographers as much as space is concerned, with a group holding that geographers aim to study space while others believe that they are out 'to analyse the significance of space for social processes'. This is generated in a way that underpins not just the natural responsibilities that space, and objects in it play for human presence on earth, but a secondary enhancement given to space as a form of signification and social mapping. Further to the foregoing, Rosa Ainley (1998:xiii), considering the Oxford Popular Dictionary (1993) definition of space, sees space as 'both actual and imagined/dramatized, with a sense of boundlessness, "in which all objects exist and move". 
The teleology of object and the attendant mobility may appear a utopia considering the various meaning-making negotiations that such a seemingly innocuous stand-point is often subjected to. As mentioned above, space would cease to be a lone agent in social constructions since the positionality of objects that coexist in, and with it, is important as it allows a classification or description of 'certain order of material objects with respect to their specific dimension' (Werlen 1993:3). This indicates that space does not only guarantee the inscription of object, element and agent, it goes ahead to perform the function of ascription, as 'space in the physical world is constituted via the experience of the subject's own body through the conscious self in movement'. Put differently, therefore, space could be used to circumscribe and promote at the same time. This goes to mean that space, as well as 'spatial relations may be expressed as forms of confinement, imprisonment, marginalisation, erasure or silencing' (McCorkle 2001:107). It must be clarified, however, that the above nature of space is both natural as well as artificial. The naturalness of the situation is a function of the realisation that some natural elements in nature could 'conspire' with space to submerge, swallow and repel as the case may be. That sense of reality leaves space as: 'the dimension of quantitative divisibility ... as the dimension of plurality, discrete multiplicity' (Massey 2005:20).

Apart from these, space can be used in classification and categorisation. This is consequent upon the ascription of value or privilege, as well as devaluation of a spatial property, at one time or the other. However, this classificatory differentiation is not limited to objects that share different constituents but includes those that parade a high level of verisimilitude in features and behaviour. Werlen (1993:142) captures this when it is posited that 'while every object can be defined or located spatially, regardless of its content, objects which are otherwise identical can be distinguished by their spatial location'. This explains the different politicisations of geographical space which in turn lead to the addition of values to achieve place naming and gating. Gated communities all over the world are fashioned to respond to the melting of different social groups within a society. Apart from the fact that social differentiations are made, using race and skin pigmentation, social exclusions and inclusions have also been brought about in various social orders based on materiality. The resultant effects of these binaries have been high toned contestations that greeted the relationships between the centre and the margin. While the first strives towards sustaining the beneficial status quo; the latter is bent on challenging and overthrowing it.

It goes without saying, therefore, that the legitimisation of power and the resistance against it leave space as 'the physical terrain and symbolic expanse 
over which contestations of power take place' (Bozzoli 2004:7). The many manifestations of space exposed so far instructively nudge us towards the analogous sharing that the public sphere promises. Michael Shafir (2004:1) sees the public space as 'a meaningful mirror of political competition', where (citing Andrei Pippidi 2000), "symbolic history" is always entangled in the separate, but nonetheless, associate process of a "clash of memories". Perhaps, it might be important to emphasise that the only idea brought into the discourse at this stage is that of 'public', given that this paper considers words like sphere and domain as interchangeable alternatives for space. However, this is not as a result of syntax and the prescriptions of synonym, but more as a result of their replaceability in the trajectory of the discourse in this paper. It should be stated that a difference in such a deployment is drawn between public space and public sphere by Charles T. Goodsell (2003:361) who holds that the first is peculiar to Hannah Arendt, ${ }^{2}$ a political and moral philosopher, while the latter is credited to the translation of the work of the philosopher, Jürgen Habermas.

\section{Gradation to Public Sphere: Theoretical Frame}

Analogous to the polemics that adorn scholarship, it has been argued that the idea of the public sphere pre-dates Habermas in Africa. This was manifested, according to Adebayo Olukoshi, ${ }^{3}$ in historical spheres provided by spaces under the Iroko tree and others, where common social events were discussed, and thereby culminating in the building of consensus through proportionality. Olukoshi hinges the Eurocentric singularity of German peculiarity, reflected in the propositions of Habermas, to other prevailing pathologies of adjectives that portend the notion that the continent of Africa is not capable of governing itself or presiding over a developmental process. Be that as it may, however, central to the discourse of the public sphere is the contribution made by Habermas $(1962 ; 1989)$ on the democratisation of mass communication. Countless ideas have been vented following the prognosis of Habermas on the universalistic application of democratic communication in the globalising world. Although the scholarship on this discourse is enormous, efforts will be made to sift some ideas around it and use them appropriately in the order of relevance. One such development is the purported replacement of hegemony by the public sphere identified by Jim McGuigan (1998:91), citing Nicholas Garnham (1995). Although McGuigan finds some aspect of the proposition which borders on media and cultural studies problematic, he concurs with the fact that 'hegemony ... carries connotations of domination, the power of the strong over the weak, even though the winning of consent rather than crude manipulation is at stake'. 
The above is a great paradox, close to the hand-in-hand coexistence of democracy and dictatorship. This is reflective of a state of servitude where coercion is not necessarily an ideal instrument.

This form, no doubt, characterises most relationships, at the different levels of social, political, cultural and economic dealings. It is then the case that the public sphere offers both the space for the ascription of hegemonic dictates and the militating responses of counter-hegemony. McGuigan (ibid) documents this in the sense that 'the public sphere is a positive idea, a good thing ... referencing a condition within which the power of the strong may be checked by that of the weak through access to ... participation in political debate and decision-making'. As much as the view shared by McGuigan above is plausible, in terms of hegemonic propositions and state instrumentality to foster imaginary inclusion, it is in itself self-negating and a far cry from the truth. The self-negation inhered in it is triggered by the fact that the state, or better still, the hegemon (or its agent) is saddled with the construction of the public sphere, using state instruments and power to transform an ordinary simple space to be imbued with characteristics that are suitable to its aspirations at one time or the other. Georges Benko and Ulf Strohmayer (1997:150) support this when they state that 'hegemonic cultural practices will always attempt to fix the meaning of space'. This means that the passive 'placeness' of space is converted through naming to achieve 'social spatialisation' which are the products of what Henri Lefebvre once called a particular 'mode of production of space' under the control of specific groups (Shields 1997:188). Further to this negation is the realisation that the weak, in the real sense of the word, are either particularly created by the state, (or its agent), or whose precarious situation is exploited and sustained by the state for the survival of hegemony. Even when the state shows a 'sincere' concern in the condition of the weak, such sincerity is not allowed to debilitate the interest of the state, hegemony and/or its agents.

'The public sphere' is also defined by Colin Sparks (1998:110), citing Habermas (1974:49), 'as a realm of our social life in which something approaching public opinion can be formed. Access is guaranteed to all citizens'. We should be mindful of the essence of social formation that is mentioned in the view of Habermas regarding the public sphere. This is more so, considering the fact that only a segment of the public is involved in the construction of such a space. The representation provided by such representatives could at best be taken as what obtains under democratic arrangements and not an ideal response to the yearnings of the masses that constitute a greater part of the public. Habermas argues that 'a portion of the public sphere comes into being in every conversation in which private individuals assemble to form a 
public body'. This public body deploys the instrumentality of the public sphere not only to vent its thoughts on issues that affect it in relation to the state, but sets out to challenge what are conceived as excesses or a misdirection or, better still, a misapplication of the resources and instruments of the state. It might be right to argue, therefore, that 'space is equally exhilarating and threatening' (Massey 2005:59) to both the public body and the state. While the state attempts to maintain a firm hold on the public sphere, the liberalisation of such space notwithstanding, the public strives to assume domination of the space by offering counter-narratives to those authored by the state. This is in tandem with the notion of bell hooks' centre and the periphery relationship, where 'power in the margin, constitutive outside, a peripheral power', is 'poised to deconstruct any center of which it is a part'. ${ }^{4}$

It is in the light of these considerations that this paper looks at the configuration of the public sphere resulting from the convocation of the South African Truth and Reconciliation Commission (TRC) by the South African government, following the demise of the apartheid order. There is for example the investment of ordinary space in town and community halls ${ }^{5}$ with symbolic meanings of social, legal and psychological regeneration. This fits very well into the abridging of the 'striking contrast' (Goodsell 2003:361) that exists between the different usages that respective disciplines bestow on the terms. There are "those who refer to it as the social realm of unfettered discourse of matters of public concern and those who conceive of it as a physical, public place, such as a town or urban plaza'. The paper argues that the state's deployment of the public sphere to achieve its programme does not preclude the public body from externalising its thoughts and ideas on such issues - most especially the collective amnesia recommended by the state and the lack of intent by the previously abused in doing this, but rather the desire on the part of the violated for a show of remorse by their oppressors.

Such a process could be matched with a genuine commitment by the government to improve the lot of the previously disadvantaged people. By this token, the public sphere behaves like what Therese Tierney (2007:80), quoting Stan Allen (1998), calls 'a field condition', which is 'any formal or spatial matrix capable of unifying diverse elements while respecting the identity of each'. Succinctly put, therefore, 'yet hegemony, as the process that naturalizes both space and social relations, is like any form of power: never fixed or inevitable but always open to exposure, confrontation, reversal, and refusal through counter-hegemonic or disidentifying practices' (Natter and Jones III 1997:150). When considered from the perspective of sociopolitical negotiations, the public sphere is capable of manifesting what Therese 
Tierney (2007:79) refers to as 'outsidedness, within the mode of presencing'. The presenceness identified is depictive of the locational positionality of the state both within the public domain and outside it, while outsidedness captures the estrangement of the masses which might not necessarily be in terms of physicality.

\section{Analysis: The South African TRC, a Public Sphere?}

Among other socio-political engagements apparent in Mda's The Bells of Amersfoort and Kani's Nothing but the Truth, the two play-texts make a statement about the South African Truth and Reconciliation Commission ${ }^{6}$ that was set up to look at the various violations of human personality committed during apartheid ${ }^{7}$ South Africa, most especially in the light of black South Africans who were oppressed 'from the cradle to the grave' (Jay A. Vora and Erika Vora 2004:302). Since the Commission required testimonies from the violated and confession from violators, the TRC tallies with the idea of the public space shared by Charles T. Goodsell (2003:364), re-echoing the view of Carr, Francis, Rivlin \& Stone, 1992, as 'the stage upon which the drama of communal life unfolds'. Goodsell proceeds further to state that 'such places are seen as a social binder for current residents and a connector to the past through accumulated personal memories and showcased historical monuments'. It should be pointed out at this stage that the notion of the public space will be construed from two approaches. One is the various physical spatial loci ${ }^{8}$ that the plays parodied and the idea of art, which is the play-texts, as a configured public space where the actual world is brought to the crucible. These texts, in a way, interrogate the use of power and how they are spawned into historical-fictional narratives, thereby correlating with Elden's (2001:152) assessment of Foucault's work, cited by Chris Philo (2004:124), as 'not just as a history of the present but as a mapping of the future'. These mappings that are done in form of art and literature, 'give form to the remnants of these histories' thereby coalescing into 'the literary public sphere' (Goode 2005:7). While the interactions in The Bells of Amersfoort are directly confrontational between two major characters, Tami and Johan, through the use of the flashback technique to re-enact the TRC, Nothing but the Truth merely presents an interrogative process through the discussions of Sipho, the major character, the daughter Thando, a teacher and an interpreter at the amnesty hearings of the Truth and Reconciliation Commission, and the daughter of his exiled brother, Mandisa, who has just returned from London for the burial of her father, Themba.

Even though the two instruments of the TRC and the engagement made with it by art could be lampooned by the modernist and postmodernist intricacies inherent in them, the intention of art, as much as possible, is to 
challenge the modernity intention of the TRC. David Clarke and Marcus Doel (2004:34b) while appraising the revelations arising out of the study of the Holocaust, have accused modernity for having 'out-rationalized (adiaphorized) the moral impulse, unburdening individuals of moral responsibility by delegating it to a higher authority', while they query postmodernity for out-aestheticizing by keeping the moral impulse and sentiment at bay, but rather choosing 'as its points of reference and orientation the traits and qualities possessed by or ascribed to the objects of spacing'. It would be sheer insensitivity to the nature of art if, in this case, it is vilified for aesthetic inclinations considering the fact that aesthetic elements provide the necessary instruments through which art navigates the trajectories of social materials that art interacts with in both fictional and factual worlds. As variegated as the relationship art shares with life is, and the case of South Africa being a very strong one, it might be right to situate art momentarily within the ambit created by Joanne Sharp (2007:275) which she has called, citing S. Lacy (1995), 'a more participatory form of public art practice ... new genre public art, wherein artists move to engage with communities and existing social struggles, to develop collaboration and dialogue with residents, and to employ different modes of address'.

However, though, this type of inclusivity was particularly peculiar to theatre in apartheid South Africa ${ }^{9}$ when it turned into an instrument of resistance. Of particular analogy is the theatre for development which was almost an elongation of the communal traditional practices of theatricality. The plausibility of what art could do to both the hegemony and people on the margin is the construction of a space which is poised at 'recreating community history, governed by desires to represent it for generations who might not know the origins of the place in which they were growing up' (Sharp 2007:279). This foregoing prognosis is saying the obvious, considering the intentions and the efforts of the Truth and Reconciliation Commission. Consequently, all truth commissions, the South African one included, 'seek to engage the dimension of the social and political space, a space of collective bargaining within civil society to spotlight terrible crimes and abuses, but also to animate public discussions and opinions' (Enwezor 2002:17).

Most nations all over the world, particularly post-colonies, are enmeshed in attempts to grapple with their past, as constituted in present realities, even when they should be, or are, forward looking. Appraising the construction and reconstruction of racial inferiority by the colonizers of Africa, Chinua Achebe (1975:70) has recommended that rather than just concentrating efforts on condemning past spoilers, people should look back and try to find out where they 'went wrong, and where the rain began to beat' them. This 
accounts for the interest of the new South African government to memorialise the despicable past of the apartheid regime, by knowing where things went wrong, and how not to recede to such abnormality. The sudden emergence of the bridge of negotiation, following the huge human abuses and degradations that the perpetuation of the apartheid prisms and the oppositions staged against it, is minimally commendable. This amount of commendation is made necessary more so, going by the fact that it was done in a sharp and rude departure from the 'amorous' and 'passionate' ${ }^{10}$ past. Most particularly, the approach employed is analogous to Mahatma Ghandi's experiment with Satyagraha, a non-violent protest strategy against racial discrimination, which he first developed in South Africa. However, the convocation of the TRC as well as its subsequent activities have been criticised most severely at one point or the other as a result of what certain groups or individuals perceive as the overbearing hold of the state, most especially its deployment as an instrument of achieving state programmes and intentions. One of those intentions was the fact that the TRC was part of other measures put in place for inscribing assurances following the players' readiness to guarantee amnesty for white apartheid leaders who were threatened with the possibility of revenge after the transition into a democratic regime. Therefore, it could be argued that 'the TRC was born of political compromise, like most truth commissions' (Jay A. Vora and Erika Vora 2004:302), or what Michael Shafir (2004:1), quoting Miklos Haraszti, calls 'the handshake tradition'.

An excerpt from the final clause of the democratic South African Constitution given below succinctly captures the negotiation between the old white rulers and the new emerging black order. Inherent in this piece are several other nuances of compromises which are apparently at variance with the aspirations of individuals, most especially victims of the brutalisation of the past, who might not have access to government hoarded opportunities with which they could seek pacification for their wounds:

The adoption of this Constitution lays the secure foundation for the people of South Africa to transcend the divisions of strife of the past, which generated gross violations of human rights, the transgression of humanitarian principles in violent conflicts and a legacy of hatred, fear, guilt and revenge. These can now be addressed on the basis that there is a need for understanding but not for vengeance, a need for reparation but not for retaliation, a need for ubuntu (the African philosophy of humanism) but not for victimization. In order to advance such reconciliation and reconstruction, amnesty shall be granted in respect of acts, omissions and offences associated with political objectives and committed in the course of the past (Jay A. Vora and Erika Vora 2004:302, quoting Krog 1998:vi). 
No doubt, the above is reminiscent of an attempt to find a smooth transition from a past history of pressures, instabilities and conflicts. This transitional endeavour has been 'equated with the construction of a new social environment based on the lessons learnt from experiences, leaving behind past abusive and dependent relationships and providing the basis for a more just, and equitable society' (Fombad 2004:193). In spite of the tabula rasa being sought by the dictates of this negotiated Constitution, the TRC processes in a way helped in inscribing some aspects of the undesirable repudiated past. However, the paradoxes occasioned by the realities of the Commission and the responses to them form the platform for the contestations between the state and certain strata of the political community.

The apartheid era that lies in the past in a way reminds one of the constituents of memory, surrounded by different propositions, most especially the transformation and promotion of private memory to the level of collective or national memorials. Further still, these personal memories were made public through the theatre which the TRC in effect staged. In another vein, Alan Baddeley (1989:51) sees memory as a system for storing information which is required 'to take in the necessary information, to store it, and to retrieve it at the appropriate time'. Baddeley however adds that 'memory is potentially fallible at each of these points'. Memory and the TRC share a correlative interdependence in that the latter is involved in achieving the former. For instance, memory, just like the TRC, 'serves to preserve intimations of the infinitive possibilities of such regressions of the human mind - and the dangers they spell for the harmonization goals of our world' (Soyinka 2000:23). This explains why the past is being 'remade' for achieving reconciliation in the present, even as the wounds of past violations are being re-opened for examination in the public sphere through the instrumentality of the TRC (Nuttall 1998:75). We should, however, be reminded of the various challenges that memory is vulnerable to, mostly when issues like recollection and forgetting are involved. It is little wonder that the past is brought to engage with the present through settlement, as against revolution, and garnished with rhetoric and narratives of how to process the future, which has been designated as nation-building.

As a result of the abundant literature around the South African TRC, some restriction of scope is required if one is to make informed prognoses as are sought in this paper. The documentation and recording of the pains of the apartheid past were considered necessary for rebuilding the new South Africa. Kader Asmal et al., (1996) carried out an explicit interrogation of the TRC and came up with reasons for its constitution. Starting from the putative note, quoting Willem de Klerk, that the 'apartheid system was darkness 
masquerading as light ... a crime against humanity', Asmal et al., posit that 'in moving away from the discredited governing consciousness of the past, we will need to build a new, shared and ceaseless debated memory of the past' (Asmal et al. 1996:9). This debate, in their view, is important in order to harness the diversity precipitated by the history of the nation and the people as well as preventing possible social, economic and political contestations. An abnegation of this responsibility would be counterproductive as the authors fear that 'for the new South Africa to abandon accurate remembrance in these early years of its birth would be the most cruel self-slaughter' (Asmal et al. 1996:12). Although the idea of remembrance as mooted by Asmal et al. is good in itself, the fact that it must be accurate and limited to the early life of the new South Africa is contentious. This is consequent on the realisation that the act of recollection and remembering cannot be accurate, as the process is liable to silences, gaps, omissions, stultifications, both deliberate and inadvertent.

The implication of the above is that repressions are deliberately achieved by the agent trying to remember the past while injuries and physical as well as psychological interferences could lead to unavoidable amnesia. Asmal et al. hint that the TRC was put in place to aid the process of reconciliation which required 'a just moral appraisal of the past' (Asmal et al. 1996:14), even though dealing effectively with the past 'is an exercise of immense difficulty interacting in a vast network of political, emotional, ethical and logistical considerations'.$^{11}$ The difficulty inherent in the preceding statement is so central to the argument of this paper since actors, most especially victims of the apartheid regime giving testimonies before the Commission, reject the process as lacking the will to effectively elicit confessions from their past violators and compensate them appropriately. The compensation being sought is not purely material, but psychological. Tensions arising from these disaffections are scarcely relieved, considering the fact that 'an important goal of the commission is to act as a catalyst for swift and thorough disclosures of past horrors in order to accelerate - and so eventually end the ready and corrosive drip of the past pathologies into the new order' (Asmal et al 1996:26). One of the scathing devaluations of the TRC is that contained in the lengthy and detailed memoir that Alex Boraine put together to capture his time as the deputy chairman of the Commission. In a review of the memoir by Stuart Wilson (2002:364), Boraine is said to have claimed that the TRC was able to settle scores but with the notion that 'some fellow commissioners subordinated the TRC's integrity to their short-time political interests at critical moments'. Succinctly put, therefore, it might be tenable to subscribe to the belief of some democratic theorists that the sponsorship 
of the public sphere, like that of the South African TRC, is 'antithetical to the core of idea of uninhibited conversation' (Goodsell 2003:368).

Some have argued that the TRC smacks of the identity of an 'exemplary civic theatre, a public hearing of private griefs (sic) which are absorbed into the body politic as a part of the deeper understanding of how the society arrived at its present position' (Catherine M. Cole 2004:219, quoting William Kentridge). The Commission has been subjected to scathing attacks from some quarters which saw the ontology of the institution as a deliberate move to secure power and protect former perpetrators. This protection, as we have seen above in the excerpt from the constitution, was supposedly achieved in the form of amnesty. Cole (2004:221) further captures this when it is submitted that:

even though the emotions expressed during the hearings were deeply felt, the Commission was not a public reckoning. Rather it was a symbol of a compromise that, most significantly, offered the possibility of amnesty to perpetrators who gave public disclosure.

The TRC process could, therefore, be succinctly captured in the view of Rory Bester (2002:164) to the effect that 'the two outstanding features of the TRC process were the public nature of the hearings and the "individualizing" of the application for amnesty'.

\section{Kani and Mda on the TRC}

This sense of resentment is captured in the two play-texts being examined in this paper for the explication of the TRC as a public space. Mda's The Bells of Amersfoort, recounts the experience of Tami, a black South African first in exile in Holland. In doing so, he conveys the feeling that the TRC was a travesty. Using the cinematic technique of segueing, Tami comes face-toface with Johan, a white South African who participated in her torture in South Africa. Johan shares a Dutch ancestry and nurtures an attachment with Holland, where he has come to undertake theological training. A deep contestation arises between Tami and Johan at their meeting, with the former demanding that the latter should account for his past misdeeds, while Johan insists that he has been given amnesty by the TRC. Johan predicates the possibility of obtaining amnesty, in line with the requirement of the TRC, on the need to make a full disclosure of past violations and accept responsibility for them. Even though he starts by claiming that he was misled by the elders who painted Tami as an enemy threatening the opportunities they have created and hoarded for him, he has to assume responsibility for his actions to earn amnesty before the TRC. ${ }^{12}$ 
Kani's Nothing but the Truth also subjects the work of the TRC to interrogation through the major character, Sipho, and his daughter, Thando, who works as an interpreter at the amnesty hearings of the Truth and Reconciliation Commission, and the latter's cousin, Mandisa, who has just returned from London to bury the cremated ashes of Themba, her late exiled father. Themba specifically requested that his body should be buried close to those of his parents, should he die in exile. His exile life was a consequence of his involvement in the liberation movements which pitted him against the apartheid state. At the personal level, he was haunted by the unforgiving attitude of his brother, Sipho, who was enraged by the 'negative influence' Themba had on his late son, Luvuyo, the suspected sexual relationship between him and his former wife as well as unhappy childhood memories. Sipho conveys his idea of forgiveness at the end with a commitment to write a letter to the president on why he should not be excluded in service delivery.

The oppositionality of the spaces occupied by the victims and the victimisers allows the former to bear witness about past violations, while the latter make a full confession of past misdemeanours. It is believed that through the confessions of the perpetrator, the violated come to understand what was responsible for their suffering and how it was carried out. This most especially allows people who have lost relations to know how they were killed and, if possible, where they were buried. ${ }^{13}$ However, this process is betrayed as a mere commitment to secure reconciliation even at the expense of victims who are still haunted by the memories and realities of their circumstances. For instance, this perceived lack of sensitivity from the government towards the victims is stated in Johan's remarks:

In any case it was not a requirement that I could only be granted amnesty if you, the victim, forgave me. So, even if you had been there, you would not have stopped the amnesty. I did what the law required. I told the truth and was granted amnesty (TBA, 151).

There is here some correspondence with Kani's Nothing but the Truth in the conversations between Thando and her father. Thando starts by expressing her frustration at the numbness she and others at the hearings suffer while Sipho says that the pointlessness of the process informed his decision not to attend the hearings anymore. The two characters proceed:

Thando: The truth does come out, and at least the families get to know what happened.

Sipho: Their version of what happened (NBT, 6).

It is apparent from the above that the victims are objectified and commodified to achieve the aim of the state, which basically is a negotiated reconciliation 
for a democratic transition. The consequence of the above is that the TRC does not offer both the victims and the perpetrators similar access to its public process of catharsis and shame, as it has been confined in one way or the other, most especially to the advantage of perpetrators, and by extension, the hegemon. Other than the fact that the full disclosure being sought by the TRC is a sham, ${ }^{14}$ as perpetrators are not committed to it, that does not in any way ameliorate the pain and hurt of the victims. Another problematisation inherent in the process of deploying amnesty and indemnity is the realisation that what the commissions accepted as the truth cannot really be taken to be so. People are unwilling to tell the truth, or there are the difficulties of remembering and recall, which place definite limits on the process of memorialisation. Thando in Nothing but the Truth laments the idea of putting something (amnesty) on nothing (lies) when she declares that: 'One gets confused sometimes. Especially when so many lies are told.' (Kani, 7) This type of pervasive and recrudescent ambiguity of truth was encapsulated by Yadh Ben Achour (2002:127) as 'truth in the sphere of politics'. The therapeutic narratological effects the stories of the victims are said to bring about could best be recognised as a promotion of an individual experience to the state of the collective memory of the nation. The lack of specificity, or better still, actualisation, of what should be given to the victim raises resentments such as found in the statement of Tami below:

You cannot absolve him on my behalf! I want justice! At the very least I must be compensated for what I went through. I want justice! ...Y You got something. You got amnesty. Even if I want to sue you for what you did to me it would be impossible, because you got amnesty. What did I get? What did the victims get for their stories? ... You and your government have forgiven each other. I am not part of that forgiveness (TBA, 151-152).

The vehement opposition shown by Tami towards Johan and the government is the best way she can deploy the public sphere to attain vindication. In the end, it is largely an indictment of the whole process. The implication is that the amnesty given, the forgiveness dispensed and the reconciliation earned are a mere repression of realities while the surface is cosmetically coated. Arguably, this form of 'publicness' is analogous to the configuration of the bourgeois public sphere where egalitarian dialogue takes place (Goode 2005:4 \& 9). Jay A. Vora and Erika Vora (2004:305) hint of this display of dissension by first recognising the South African TRC as a political configuration, just like other TRCs and conclude that 'the TRC was controversial and met with resentments'. The Reparation and Rehabilitation Committee was said to have recommended, in some cases, that victims of past violations should be paid $\mathrm{R} 26,000$ for a period spanning six years, but the government declined because 
of its unpreparedness to accept 'responsibility for the wrongs of its predecessor', in spite of the argument by Archbishop Desmond Tutu, the chairperson of the TRC, 'that without some financial reparation, those who told their stories would feel cheated' (Fomdad 2004:199).

Critically speaking, the quest for reparation and compensation by the victim would have amounted to a commodification of the bodies and pains of the victims that were violated under the apartheid regime. It goes almost without saying that the deployment of retributive justice would not have brought the victim the kind of compensation that would not reduce the charred and cherished past to mere materiality either. The potency of these 'sacred' memories would be lost the moment they were purchased for a monetary price, since every sense of guilt would be eliminated, reducing the process to that of commercial bargaining. One could argue that the best way to compensate the victims would be for the government to galvanise the process of citizenship transformation so that the victims of past brutality would be encouraged by the sacrifice they made even as the future could also be guaranteed for all and sundry. It would then be like the case of forgiving their past for the sake of their present and tomorrow, since "we have seen that the process does not always really alleviate the suffering and frustration of the victims' (Achour 2002:113).

It is also the case that few of the perpetrators were forgiven directly by the victims because 'people felt raw, angry, upset, the more so because not many of the perpetrators had been able to show much spontaneous human emotion' (Sachs 2002:55). This should not be unexpected, considering the fact that the process was precipitated purely by the urgency of the political realignment needed to ward off the acts of revenge from the resistance movements amidst international condemnation of the apartheid regime. Like Johan, most of the unrepentant perpetrators claim that they are not really culpable because they were following orders from their superiors, while others like the former President, P. W. Botha, took their stand on reasons of state. The grounds of excuses in the above notwithstanding, the question is how can the sincerity of remorse be demonstrated? Repentance, in the view of Yadh Ben Achour (2002:125), 'loses its authenticity when it is performed under constraints, or out of purely material interest', as is almost always the case in the South African situation. The resultant contestations they lead to is explained by Mahmood Mamdani (2000:180-181) who posits that 'the more beneficiaries appear complacent, indifferent, callous and lacking in empathy, the more victims are outraged. They feel forgiveness to be undeserved. The more they feel so, the more they demand: justice'. Mamdani concludes that 'the TRC ends up fuelling the very demand it set out to displace: justice'. 
While Tami in Mda's The Bells of Amersfoort is mild in making her request for justice, Mandisa, the cousin of Sipho in Kani's Nothing but the Truth, believes that people should be allowed to revenge the wrongs done them in the past, or at least, ensure that the perpetrator pays for his wrongs. She specifically queries why the perpetrators of the deaths of people like Ruth First, wife of Joe Slovo, should not be made to face the consequences. Thando, her cousin and the interpreter to the commission, believes that the South African nation is not ready to go the way of Nuremberg as the struggle for liberation is personified as the struggle for and by all. She justifies the granting of amnesty to someone like Craig Williamson to full disclosure ${ }^{15}$ which conforms to the rules and requirements of the TRC. Apart from this, Thando reminds Mandisa of individuals like Derby-Lewis, Janus Walus ${ }^{16}$ and the police who killed the Pebco Three. Thando cements her position by making reference to the forgiving spirit of Nelson Mandela who was incarcerated for 27 years on Robben Island.

It is implicitly stated that the idea of forgiveness and the giving of amnesty are principally the project of the first democratic president of the country, Nelson Mandela, who has been promoted to the place of an icon of peace. Although this decision in favour of reconciliation through restorative justice helps to halt the killings and violence that characterised the apartheid era, certain individuals benefited directly from the establishment of a democratic government while others, most especially the mass of people, merely had their painful memories displayed in the public domain of the TRC hearings. To this set of people, the TRC is in a way a reopening of the wounds of the past. The healing of the wounds might, however, be hastened by the 'knowing' occasioned by the confessions of the violators and the externalisation achieved through their testimony, as well as the open identification made with them by the hired comforters and members of the commission. It is on record, for instance, that Archbishop Tutu, the chairperson of the commission was in tears while listening to the testimony of victims (Sachs 2002:49).

The outcome of the negotiations by the agents of the state and those of the victims in the public sphere constituted by the TRC is illustrated by Sipho who has the dream of becoming the Chief Librarian of the public library in Port Elizabeth. The snag of his dream is that he is believed to be too old for the position. After his lamentation that he was not considered too old in 1994 and 1999 when he voted for two democratic presidents, Nelson Mandela and Thabo Mbeki, he complains that: '...suddenly I am too old to be empowered' (NBT, 51). Sipho's complaint is that some people have chosen to personalise the gains of the struggle, which they consolidate through the 
TRC compromise. As if reviewing the conditions that determine who should benefit from the immediate and direct dividends of the new South Africa, Sipho declares that:

I was part of the struggle. I too suffered as a black person. I went to the marches like everyone else. I might not have been detained. I might not have been on Robben Island. I did not leave this country, but I suffered too. The thousands that attended those funerals on Saturdays, that was me. The thousands that were tear gassed, sjamboked by the police, mauled by Alsatian dogs, that was me. When Bishop Tutu led thousands through the streets of white Port Elizabeth, that was me. I WAS THOSE THOUSANDS! I too deserved some recognition, didn't I? (NBT, 51-52).

Sipho seems to be challenging the privileging of certain individuals like President Nelson Mandela and others who assumed 'unrestricted' access to the machinery of state by reasons of their involvement in the liberation struggle. ${ }^{17}$ As a result, Sipho appears to be making a deconstruction of heroism and the promotion to the place of iconicity in the South African state. Apart from Nelson Mandela and others who had their unpleasant past memorialised and compensated for, Sipho is making a case for himself and other thousands who have the credentials of a charred past that would get them a place in the state platform. Although he might not be asking for a seat in Parliament or the State House, he, like Tami, nurses the expectation of a better life and being in the new South African nation.

Sipho then elaborates on what he believes is his own idea and process for the deployment of amnesty by using the death of his son, Luvuyo, who was killed as a result of his activities in the liberation struggle. Sipho claims that Luvuyo was shot by a white policeman during the administration of $\mathrm{F}$. W. de Klerk. He wants the policeman to be sent to jail while he awaits trial after which he would be found guilty for killing Luvuyo because he was black. His being pronounced guilty should be followed by his incarceration at St. Alban's Prison outside Port Elizabeth, where he will be subjected to the kind of experiences peculiar to murderers. One is however startled by Sipho's response to the probing of Thando on whether he will forgive the white culprit after he had been made to undergo this punishment. Even though Sipho says he will be willing to consent to the policeman's amnesty, he is not prepared to forgive the white apartheid policeman:

Sipho: It's not about me being happy or not, forgiving him or not. It's about justice. That's what it's about. So that my soul can rest. So that I can say to myself 'yes, justice has been done' (NBT, 54). 
Sipho however follows the trajectory of forgiveness the state is seeking for the process of reconciliation as he declares that he has forgiven his late brother, Themba, for his wrongs. He compares this with the forgiveness he extends to the white people in spite of 'what they did to us in this country...' (NBT, 56). The centrality of the notion of forgiveness to the responsibilities of the state and, by extension, the TRC, is quite a touchy one. Since this paper does not intend to interrogate this manifestation within the whole, it would like to reiterate the view of Mark Sanders (2007:88), quoting Derrida, that however profound reconciliation and the work of mourning are, 'they do not amount to forgiveness'. The ideal of forgiveness in the dealings between black and white South Africans has been constructed on the traditional dictates of Ubuntu, ${ }^{18}$ which more significantly paints the need for the protection of human rights.

\section{Conclusion}

This paper has attempted to show how art has been dually deployed to reenact a public space through the various sites constructed through the work of the TRC. Both the parodies of the TRC implicit in the two texts, and the interrogation the two play-texts have achieved as a whole, challenge the privatisation of the public sphere by the state. These two possibilities of the public sphere in the textual materials are a follow-up and, therefore, a response, if not a reaction to the actual public domain of the TRC. Even though it is apparent that the state was able to impose its own case for the TRC public sphere and why it was inevitable, such successes are challenged by the previously marginalized and brutalised whose cries of anguish and disaffection constitute a profound embarrassment for the hegemon. Apart from such plays as these two considered here, the disenchantment of the majority towards the abuse of the public sphere by the government has been embodied in art, other public spheres in print and electronic media, and also evidenced in the rejection of the state-sponsored public sphere. One can cite the words of Ruston Bharucha (2002:370) that 'most reconciliations are fragile, partial, and in constant need for renewal'. We see both drama and the TRC exhibiting the fluidity, mutability and deviancy of truth as 'the most illusory places in the world, where it is legitimate to lie knowingly ... and yet truth matters' (Bharucha 2002:362-363).

\section{Notes}

1. For instance, Gary Bridge (2004:61a) re-echoes the contribution of Foucault's 'notion of governmentality in the discursive construction of space for politics'. 
2. According to Charles T. Goodsell (2003:362), Arendt defines the public space as 'the sphere of public action essential to democratic citizenship. It is the realm in which citizens engage in collective deliberation and in joint action on behalf of the public good', while Habermas says the public sphere involves individuals' private conversations and discussions that are directed at the interest of the public. Succinctly put, Goodsell believes 'Arendt's public space is primarily an arena of political action, whereas Habermas's public sphere is essentially a medium of public communications'.

3. Olukoshi was speaking at the First Plenary Working Session of the CODESRIA Twelfth General Assembly held in Yaoundé, Cameroon, on 8 December, 2008.

4. Quoted in Wolfgang Natter and John Paul Jones III (1997:151).

5. Benno Werlen (1993:174) calls these 'socially constructed artefacts'.

6. The South African TRC, which was headed by Archbishop Desmond Tutu, started its assignment on 1 February 1996, after the approval given to it by the parliament in July 1995. President Nelson Mandela appointed seventeenth commissioners of the TRC, who, together with eleven co-opted members, formed three committees: the Human Rights Violations Committee, the Amnesty Committee, and the Reparation and Rehabilitation Committee. The TRC proceedings ended on 31 July 1998, and the final report was submitted to President Nelson Mandela on 29 October 1998 (see Ruston Bharucha 2002:362). Similar Commissions (15), according to Jay A. Vora and Erika Vora (2004:303), were established in countries like Argentina, Bolivia, Chile, Germany, the Philippines, and others. The South African TRC activities were carried out by three major committees: the Amnesty committee, the Human Rights Violations Committee, and the Reparation and Rehabilitation Committee (Charles Manga Fombad 2004:196).

7. The system was declared a crime against humanity.

8. These include the 'town halls, civic centres, and churches' used across the country (Jay A. Vora and Erika Vora (2004:305).

9. Literature in apartheid South Africa was reduced to an instrument of resistance because of the vitriolic engagements it made with the debased government and the prisms of what it stood for. Apart from deploying theatre most particularly for exposing the ills lurking around, it was used to mobilise people from both within and without to condemn it. Because this proved to be an effective instrument, some scholars have feared what literature in postapartheid South Africa would engage with. This apprehension has been proved to be unfounded as literature in the new South Africa is still involved in the interrogation of the minimal life of the people.

10. Both words are designative of the supremacy and purity that most of the white community was interested in.

11. Asmal et al., in this second quote are quoting the court on the Act establishing the TRC. 
12. Mzamo, the chairman of the fictional TRC in the play-text, who is dressed in 'bishop's maroon' to capture the signification of the actual TRC, reminiscences about the constitutional requirements for amnesty in one of his conversations with Johan: 'And now you want amnesty? You know the conditions for amnesty: full disclosure and full acceptance of your guilt and, of course, a political motive for your crimes' (TBA, 150).

13. So many secret graves were said to have been identified with the bones of victims removed to be given proper burial. Although this removal might at the surface be taken as a rupturing of the souls of the dead, such is however attenuated when the temporary burial sites are viewed as a prison of a sort. Therefore, the removal could be taken as a form of freedom and reintegration.

14. Jay A. Vora and Erika Vora (2004:309) re-echoed the fact that most perpetrators deliberately withheld the truth and told what they call 'half-truths and lies'. In another vein, Charles Manga Fombad (2004:198) notes that more than 7000 applications for amnesty were submitted to the committee before the deadline, most of which came from people already in prison. Fombad further claims that members of former apartheid government displayed impunity as they argued that they did not commit any crime. Jay A. Vora and Erika Vora (2004:319) also support this argument by stating that some Afrikaners were opposed to the idea of the TRC. Specifically, P. W. Botha, former prime-minister and president of South Africa, was said to have refused to appear before the TRC.

15. Put in another way Sipho is parodying the TRC, saying 'the truth, the whole truth and nothing but the truth', whence the title of the play is derived (NBT, 49).

16. They are said to have murdered Chris Hani (NBT, 29).

17. The wrangling in the ANC after President Thabo Mbeki was recalled, and following the decision of certain members to form a splinter party, has seen such members being described as right-opportunists. This trend further casts an aspersion on the idea of transposing comradeship to leadership.

18. Mark Sanders (2007:25) claims that the Truth and Reconciliation Commission's report makes reference to the judgement of Judge Yvonne Mokgoro ' $[\mathrm{u}]$ buntu, generally translated as "humanness", express itself metaphorically in umuntu ngumuntu ngabantu — "people are people through other people".

\section{References}

Achebe, C., 1975, Morning Yet on Creation Day, New York: Anchor Press.

Ainley, R., ed., 1998, 'Introduction', New Frontiers of Space, Bodies and Gender, London: Routledge, pp. xiii-xvii.

Asmal, K. et al., 1996, Reconciliation Through Truth: a Reckoning of Apartheid's Criminal Governance, Cape Town: David Philip Publishers.

Baddeley, A., 1989, 'The Psychology of Remembering and Forgetting', Memory, History, Culture and the Mind, ed., Thomas Butler, New York: Basil Blackwell Ltd, pp. 33-60. 
Ben Achour, Y., 2002, 'The Order of Truth and the Order of Society', Experiments with Truth: Transitional Justice and the Process of Truth and Reconciliation, Document 11_Platform 2, Okwui Enwezor et al., eds., Ostfildern-Ruit: Hatje Cantz Publishers, pp. 123-134.

Bester, R., 2002, 'Trauma and Truth', Experiments with Truth: Transitional Justice and the Process of Truth and Reconciliation, Document 11_Platform 2, Okwui Enwezor et al., eds., Ostfildern-Ruit: Hatje Cantz Publishers, pp. 155-173.

Bharucha, R., 2002, 'Between Truth and Reconciliation: Experiments in Theater and Public Culture', Experiments with Truth: Transitional Justice and the Process of Truth and Reconciliation, Document 11_Platform 2, Okwui Enwezor et al., eds., Ostfildern-Ruit: Hatje Cantz Publishers, pp. 361-388.

Bozzoli, B., 2004, Theatre of Struggle and the End of Apartheid, Johannesburg: Wits University Press.

Bridge, G., 2004, 'Pierre Bourdieu', Key Thinkers on Space and Place, eds., Phil Hubbard, Rob Kitchin and Gill Valentine, London: SAGE Publications Inc., pp. 59-64.

Clarke, D. and Doel, M., 2004, 'Zygmunt Bauman', Key Thinkers on Space and Place, eds., Phil Hubbard, Rob Kitchin and Gill Valentine, London: SAGE Publications Inc., pp. 33-39.

Cole, C.M., 2004, 'Theatres of Truth, Acts of Reconciliation: the TRC in South Africa', African Drama and Performance, eds., John Conteh-Morgan and Tejumola Olaniyan, Bloomington: Indiana University Press, pp. 219-226.

Enwezor, O., 2002, 'Introduction', Experiments with Truth: Transitional Justice and the Process of Truth and Reconciliation, Document 11_Platform 2, Okwui Enwezor et al., eds., Ostfildern-Ruit: Hatje Cantz Publishers, pp. 13-17.

Fombad, C.M., 2004, 'Prospects for Peace Building through Truth Commissions in Africa', The Quest for Peace in Africa: Transformations, Democracy and Public Policy, ed., Alfred G. Nhema, Utrecht: International Books, pp. 189-219.

Goode, L., 2005, Jurgen Habermas: Democracy and the Public Sphere, London: Pluto Press.

Goodsell, C.T., 2003, 'The Concept of Public Space and Its Democratic Manifestations', American Review of Public Administration, Vol. 33, No. 4, pp. 361-383.

Kani, J., 2002, Nothing But the Truth, Johannesburg: Witwatersrand University Press.

Kok, de I., 1998, 'Cracked Heirlooms: Memory on Exhibition', Negotiating the Past: the Making of Memory in South Africa, eds., Sarrah Nuttall and Carli Coetzee, Cape Town: Oxford University Press, pp. 57-71.

Mamdani, M., 2000, 'The Truth According to the TRC', The Politics of Memory: Truth, Healing and Social Justice, eds., Ifi Amadiume and Abdullahi AnNa'im, London: Zed Books, pp. 176-182.

Massey, D., 2005, For Space, London: SAGE Publications. 
McCorkle, J., 2001, 'Gender, Text and Space in J.M. Coetzee's Fiction', Spaces and Crossings: Essays on Literature and Culture in Africa and Beyond, eds., Rita Wilson and Carlotta von Maltzan, New York: Peter Lang, pp.107-123.

McGuigan, J., 1998, 'What Price the Public Sphere?', Electronic Empires: Global Media and Local Resistance, ed., Daya Kishan Thussu, London: Arnold, pp. 91-107.

Mda, Z., 2002, Fools, Bells, and the Habit of Eating (Three satires), Johannesburg: Witwatersrand University Press.

Natter, W. and J.P. Jones, 1997, 'Identity, Space, and Other Uncertainties', Georges Benko and Ulf Strohmayer, eds., Space and Social Theory, Oxford: Blackwell Publishers Ltd, pp. 141-161.

Nuttall, S., 1998, 'Telling “Free" Stories? Memory and Democracy in South African Autobiography Since 1994', Negotiating the Past: the Making of Memory in South Africa, Sarah Nuttall and Carli Coetzee, eds., Cape Town: Oxford University Press, pp. 76-88.

Olukoshi, A., 2008, 'Bringing the Public Sphere into African Democratic Theory', Paper presented during the First Plenary Session of the CODESRIA 12th General Assembly, at Yaoundé, Cameroon, on 8th December.

Philo, C., 2004, 'Michel Foucault', Key Thinkers on Space and Place, eds., Phil Hubbard, Rob Kitchin and Gill Valentine, London: SAGE Publications Inc., pp. 121-128.

Ricoeur, P., 2004, Memory, History, Forgetting, Translated by Kathleen Blamey and David Pellaver, Chicago: The University of Chicago Press.

Sachs, A., 2002, 'Different Kinds of Truth: The South African Truth and Reconciliation Commission', Experiments with Truth: Transitional Justice and the Process of Truth and Reconciliation, Document 11_Platform 2, Okwui Enwezor et al., eds., Ostfildern-Ruit: Hatje Cantz Publishers, pp. 43-60.

Sanders, M., 2007, Ambiguities of Witnessing: Law and Literature in the Time of a Truth Commission, Johannesburg, Wits University Press.

Shafir, M., 2004, 'The Politics of Public Space and the Legacy of the Holocaust in Postcommunist Hungary', An abridged version of the Paper 'Hungarian Politics and the Legacy of the Holocaust Since 1989', presented at the 16-18 March 2004 Symposium 'The Holocaust in Hungary: Sixty Years Later', Washington, D. C., The United State Holocaust Memorial Museum.

Sharp, J., 2007, 'The Life and Death of Public Spaces: Public Art and Community Regeneration in Glasgow', Cultural Geographies, pp. 274-292.

Shields, R., 1997, 'Spatial Stress and Resistance: Social Meanings of Spatialization', Georges Benko and Ulf Strohmayer, eds., Space and Social Theory, Oxford: Blackwell Publishers Ltd, pp. 186-202.

Soyinka, W., 2000, 'Memory, Truth and Healing', The Politics of Memory: Truth, Healing and Social Justice, eds., Ifi Amadiume and Abdullahi An-Na'im, London: Zed Books, pp. 20-37. 
Sparks, C., 1998, 'Is there a Public Sphere?', in Electronic Empires: Global Media and Local Resistance, ed., Daya Kishan Thussu, London: Arnold, pp. 108124.

Tierney, T., 2007, Abstract Space: The Beneath the Media Surface, Oxon: Taylor $\&$ Francis.

Vora, J.A. and Vora, E., 2004, 'The Effectiveness of South Africa's Truth and Reconciliation Commission: Perceptions of Xhosa, Afrikaner, and English South Africa', Journal of Black Studies, Vol. 34, No 3, pp. 301-322.

Werlen, B., 1993, Society, Action and Space: An Alternative Human Geography, London: Routledge. 